\title{
Genes and mutations causing retinitis pigmentosa
}

\author{
SP Daiger, LS Sullivan, and SJ Bowne \\ Human Genetics Center, School of Public Health, The University of Texas Health Science \\ Center, Houston, TX, USA
}

\begin{abstract}
Retinitis pigmentosa (RP) is a heterogeneous set of inherited retinopathies with many diseasecausing genes, many known mutations, and highly varied clinical consequences. Progress in finding treatments is dependent on determining the genes and mutations causing these diseases, which includes both gene discovery and mutation screening in affected individuals and families. Despite the complexity, substantial progress has been made in finding RP genes and mutations. Depending on the type of RP, and the technology used, it is possible to detect mutations in 30$80 \%$ of cases. One of the most powerful approaches to genetic testing is high-throughput 'deep sequencing', that is, next-generation sequencing (NGS). NGS has identified several novel RP genes but a substantial fraction of previously unsolved cases have mutations in genes that are known causes of retinal disease but not necessarily RP. Apparent discrepancy between the molecular defect and clinical findings may warrant reevaluation of patients and families. In this review, we summarize the current approaches to gene discovery and mutation detection for RP, and indicate pitfalls and unsolved problems. Similar considerations apply to other forms of inherited retinal disease.
\end{abstract}

\section{Keywords}

genetic screening; inherited retinal diseases; next-generation sequencing; phenotype; genotype reconciliation; retinitis pigmentosa; targeted-capture sequencing

\begin{abstract}
Inherited retinal diseases affect more than 200,000 Americans and millions of individuals worldwide (1-3). Dozens of different types of disease are included in this set of diseases, and more than 190 genes have been identified as the cause of one or another form of inherited retinal disease $(4,5)$. Retinitis pigmentosa $(\mathrm{RP})$ accounts for approximately one-half of cases. RP itself is highly heterogeneous: mutations in more than 50 genes are known to cause non-syndromic RP and nearly 3100 mutations have been reported in these genes (5, 6). Syndromic forms of RP are equally heterogeneous: mutations in 12 genes cause Usher syndrome and 17 genes are associated with Bardet-Biedl syndrome; together these two diseases account for another 1200 pathogenic mutations. In addition to genetic and mutational heterogeneity, different diseases may be caused by mutations in the same gene, symptoms of different diseases may overlap, and there is extensive variation in clinical expression even among individuals sharing the same mutation in the same gene.
\end{abstract}

\footnotetext{
(C) 2013 John Wiley \& Sons A/S.

Corresponding author: Stephen P.Daiger, PhD, Human Genetics Center, School of Public Health, The University of Texas Health Science Center, 1200 Herman Pressler Drive, Houston, TX 77030, USA. Tel.: +1 713500 9829; fax: +1 713500 0900; stephen.p.daiger@uth.tmc.edu.

Conflict of interest

The authors declare no conflict of interest.
} 
Despite the complexity, significant progress has been made in recent years in identifying novel RP genes and in screening patients for pathogenic mutations. This is partly the result of development of high-throughput mapping and sequencing techniques, but is also testimony to the large number of investigators and research groups working in this area. In the past two decades, the number of research groups in the world focused on RP genetics has gone from a handful to dozens. The potential options for treatments have also increased markedly. The purpose of this review is to provide an overview of the current status of RP genes. References are largely chosen for illustration; a more comprehensive list is found in RetNet, http://www.sph.uth.tmc/edu/retnet (5). Inherited retinopathies as a broad class of diseases are reviewed in other publications $(4,7)$. This is a fast-moving field and it is encouraging to note that any review will be out of date sooner rather than later.

\section{Heterogeneity}

Retinitis pigmentosa is a progressive, degenerative disease of the retina leading to profound loss of vision or blindness (3). The clinical hallmarks of RP are night blindness, often starting in adolescence, followed by progressive loss of peripheral vision and subsequent loss of central vision. By midlife, RP patients may retain a few degrees of central vision but in many cases the disease culminates in complete blindness. Findings on retinal examination include 'bone spicule' pigmentary deposits, retinal vessel attenuation, and characteristic changes in electroretinogram (ERG) patterns. At a cellular level, a simplified view of RP is progressive dysfunction and loss of rod photoreceptors, first affecting night vision in the rod-rich mid-peripheral retina, then progressing into the cone-rich central retina, with eventual loss of cones either as a direct result of the disease process or secondary to the death of rods.

Within this broad picture, though, there is considerable variation in age of onset, rate of progression, rod vs cone involvement, involvement of other retinal cells such as RPE, secondary symptoms such as cystic macular edema, and many other features. RP which is present at birth or soon after is often referred to as Leber congenital amaurosis (LCA). RP may occur alone, as non-syndromic RP, without other clinical findings, or as syndromic or systemic RP with other neurosensory disorders, developmental abnormalities, or complex clinical phenotypes. Usher syndrome is RP with congenital or early onset deafness. BardetBiedl syndrome (BBS) is RP with kidney disease, obesity, polydactyly and developmental delay. RP may also be secondary to systemic disorders such as mitochondrial diseases or various forms of degenerative cerebellar disease. For simplicity, this review is limited to non-syndromic RP, Usher syndrome and BBS (for one reason, because the diseases overlap). Other syndromic and systemic forms of RP are listed in RetNet (5).

Retinitis pigmentosa is exceptionally heterogeneous. This includes (i) genetic heterogeneity - many different genes may cause the same disease phenotype; (ii) allelic heterogeneity there may be many different disease-causing mutations in each gene; (iii) phenotypic heterogeneity - different mutations in the same gene may cause different diseases; and (iv) clinical heterogeneity - the same mutation in different individuals may produce different clinical consequences, even among members of the same family. The extent of heterogeneity of RP can be confusing to patients and clinicians alike, and is a confounding factor in diagnosis.

The most obvious complications are genetic and allelic. Currently, mutations in 56 genes are known to cause non-syndromic RP (Table 1). Twelve genes account for Usher syndrome and 17 account for BBS (Tables 2 and 3). If genes for LCA and for other syndromic or systemic forms of RP are included, at least 100 'RP-related' genes are known. Allelic or mutational heterogeneity is equally striking. Counting all the genes known to cause non- 
syndromic RP, nearly 3100 disease-causing mutations are reported in mutation databases (Table 1). Discounting over-laps with non-syndromic RP, genes causing Usher syndrome and BBS account for at least another 1200 mutations (Tables 2 and 3).

Although some of the publically reported mutations may, later, turn out to be nonpathogenic, this is still a significant underestimate because many novel mutations are listed in private databases and are not yet in the public domain. Among other concerns, there is need for more systematic collection of mutation phenotype-genotype information for inherited retinal diseases, a need addressed, for example, by the Leiden Open Variation Database (8).

Equally confusing is the overlap between disease types, disease names, and clinical consequences. First, different mutations in the same gene may cause distinctly different conditions. For example, even though most rhodopsin mutations cause autosomal-dominant RP and most RPE65 mutations cause recessive LCA, some rhodopsin mutations may be recessive acting and some RPE65 mutations may be dominant acting (9-13). Usher syndrome mutations are recessive and cause both deafness and RP, but mutations in two Usher genes, CLRN1 and USH2A, may cause recessive RP only $(14,15)$.

For non-syndromic RP, mutations in 23 genes are known to cause autosomal-dominant RP, 36 genes cause recessive RP, and 3 genes cause X-linked RP (5). However, Table 1 shows that several of these diseases overlap with each other and Tables 1-3 show that many genes cause multiple diseases. In some cases the 'secondary' disease is rare (e.g. recessive rhodopsin or dominant RPE65 mutations), but in some cases it is common (e.g. recessive RP and USH2A). Generally, there is no simple mapping between gene and disease in most cases.

Finally, even identical mutations within the same gene may produce different clinical findings. Variation between individuals in age of onset or rate of progression is not unexpected, but, for example, mutations in PRPF31 are non-penetrant in some family members, $(16,17)$ and mutations in PRPH2 (RDS) produce a wide range of macular, peripheral or pan-retinal symptoms $(18,19)$. One consequence is that members of the same family, seen by different clinicians, may have diagnoses that are consistent with findings in the individual but inconsistent with the family. Overall, there is considerable overlap between diseases caused by RP genes even though different names are given to specific types of disease. This is well illustrated by the over-lapping disease nomenclature proposed by Berger et al. for inherited retinal diseases (4).

Fortunately, molecular techniques allow identification of the underlying gene and mutation or mutations in many cases, adding a molecular diagnosis to the clinical diagnosis.

Nevertheless, in some cases this leads to apparent contradictions that require further analysis to resolve.

\section{Technical approaches}

The standard techniques for gene discovery and mutation detection - linkage mapping and DNA sequencing - have been used for many years. However, development of high-density and high-throughput techniques in the past 10 years has increased the power of these methods by orders of magnitude.

For linkage mapping, high-density SNP (single-nucleotide polymorphism) arrays, such as the AFFYMETRIX 6.0 SNP/CNV array, (20) allow linkage testing against nearly 1 million genetic markers. For practical purposes, these are often collapsed to around 10,000 mostinformative markers, with known relationships to contiguous markers. However, even with 
smaller marker sets, there is a serious issue of the large number of independent tests (multiple comparisons) leading to apparent linkage 'hits' by chance alone. Fortunately, there are many more, highly-variable genetic markers in the human genome that can be used to refine linkage mapping (9). Several RP genes have first been localized by linkage mapping in recent years (21-25).

One consequence of availability of dense SNP marker sets is that it is possible to identify regions on homologous chromosomes that are identical-by-descent, that is, regions on a matching pair of chromosomes that derive from a single chromosome in a relatively recent ancestor. This identifies the chromosomal location of identical recessive mutations in families with consanguinity or recent within-family matings. This approach to mapping recessive genes is called homozygosity mapping or autozygosity mapping (26). It has been very productive in identifying RP genes in inbred families and in ethnic populations where inbreeding is common (27-31). Surprisingly, even in families without evidence of consanguinity, recessive RP mutations are more often identical-by-descent than expected, thus expanding the utility of homozygosity mapping (26).

Methods for detecting mutations at a DNA sequence level include Sanger sequencing, still called the gold standard of sequencing, array-based detection of specific mutations (e.g. APEX, 'array-primer extension' (32-34)), ultra-high-throughput sequencing and others. Of these, the major advance in recent years in finding RP genes is application of ultra-highthroughput sequencing, generally referred to as next-generation sequencing (NGS) (35). Conventional Sanger sequencing is usually done using semiautomated, multilane capillary electrophoresis (itself a major improvement over earlier methods). In contrast, NGS does millions of sequencing runs in parallel on micron-sized beads or in comparable micro-wells, completing up to a billion base-pair reads per run. That is, NGS sequencing is at least 1000 times faster than conventional sequencing, and much less expensive per sequence.

There are several NGS methods and numerous distinct applications $(36,37)$. What most methods have in common is short-read, shot-gun sequencing: DNA is first fragmented into short sequences, read lengths are in the range of 100 to 200 base pairs, and computational methods are used to 'reassemble' the short reads into larger constructs. This allows highly accurate, extremely rapid sequencing of large regions of the human genome, but certain features of human DNA, such as deletions and rearrangements, expanded repeats, and haplotypes, are not accessible to NGS without additional steps. Also, because of the sheer volume of data produced by NGS, dedicated bioinformatic resources are required to fully utilize the results.

Despite these limitations, NGS has been exceptionally productive in gene discovery and mutation detection for RP. Broadly, there are three NGS strategies: whole-exome NGS, whole-genome NGS and targeted-capture NGS. Whole-exome NGS involves capture of all protein-coding regions, that is, all exons, constituting about $1.5 \%$ of the human genome, followed by NGS. By definition this technique is limited to finding mutations in coding regions only, but nonetheless it has led to identification of several RP genes and novel mutations $(9,38,39)$. Whole-genome NGS covers nearly all the human genome (about 98\%), and avoids potential artifacts introduced by exon capture, but is not yet in routine use for gene discovery. The principal limitations are sequencing costs, and management and analysis of the resulting massive data sets. However, it is likely that whole-genome sequencing will become routine in the near future, especially with development of 'third generation' technologies (40).

Targeted capture, the third NGS strategy, limits testing to exons of known disease-causing genes (41) - in the case of retinal diseases, for example, testing only the 190-plus genes in 
RetNet (5). The disadvantage, of course, is that no new genes can be identified. The advantages are that the analysis 'space' is much smaller, more is known, a priori, about each gene, and costs are much lower. Thus this is currently an optimal approach to mutation screening for RP, with many applications (42-47).

Finally, some mutations are not easily detected by conventional sequencing or NGS, particularly large deletions and rearrangements. Some deletions can be detected by SNP arrays, and the Affymetrix 6.0 SNP/CNV arrays includes copy-number probes (CNVs) for deletion detection (20). PCR-amplification based methods, such as MLPA or qPCR, can detect much smaller deletions. This is a significant issue as nearly $3 \%$ of cases of autosomaldominant RP are caused by deletions in PRPF31 not detectable by sequencing $(17,48)$. Similar deletions and rearrangements are found in ABCA4, a common cause of recessive $\mathrm{RP}$, and in RPGR, the principal cause of X-linked RP (49). However, X-linked deletions are easily detected in hemizygous males, and the principal problem in sequencing RPGR is the repetitive nature of ORF15.

\section{Current status of gene discovery and mutation detection}

Identification of novel genes causing inherited retinal diseases, including RP, has progressed at a steady, linear rate for nearly 20 years (Fig. 1). Although the tools for gene discovery are much more powerful, the steady rate in recent years suggests that, in general, each new gene is rarer than preceding genes and thus more difficult to detect. Whole-genome NGS may accelerate gene discovery, but it is possible that the remaining, unknown RP genes are very rare. However, there is no meaningful way to predict the remaining number of RP genes.

The meaningful questions in this context are (i) in what fraction of RP patients can diseasecausing mutations be detected today, and (ii) when will it be possible to find mutations in nearly all patients, say, at least $95 \%$ ? The answer to the first question depends on the technology used and the type of RP. Combining results from conventional Sanger sequencing and targeted-capture NGS, using rough estimates, it is possible to detect the underlying pathogenic mutation or mutations in $20-30 \%$ of autosomal recessive RP cases, $60-70 \%$ of autosomal-dominant cases, $80-85 \%$ of X-linked cases, and more than $85 \%$ of Usher and BBS cases $(44,50)$ [and S.P. Daiger, unpublished data].

Simplex (isolated) RP cases are more complicated. Traditionally, simplex RP cases are predicted to be recessive, with unaffected carrier parents. This is true in many cases, but there are exceptions. At least $15 \%$ of males with RP and no other affected family members have mutations in the X-linked genes RPGR or RP2 (51). De novo autosomal-dominant mutations account for at least $1-2 \%$ of simplex cases $(45,52)$. Targeted NGS identifies mutations in 19-36\% of simplex RP cases, but confirming pathogenicity in these cases is problematic (44-47). A further complication is that the carrier frequency for all inherited retinal disease mutations in unaffected individuals may exceed 20\% (53). That is, each mutation is extremely rare, but there are so many genes and so many mutations, that in aggregate they are common.

Prediction is risky, but given rapid advances in DNA sequencing methods, and continued identification of new RP genes, it is reasonable to expect that within 5 years it will be possible to detect the disease-causing gene and mutation or mutations in $95 \%$ of patients. This is assuming that most of the remaining cases are monogenic, that is, caused by a single gene in each individual. Since digenic forms of RP and triallelic forms of BBS are already known, polygenic inheritance of retinal diseases cannot be discounted $(54,55)$.

Finally, genetic diagnosis of RP may change the family diagnosis or raise questions about the relationship between genotype and phenotype. For example, at least $8 \%$ of families with 
a provisional diagnosis of autosomal-dominant RP actually have mutations in X-linked RP genes (56). Mutations in genes commonly associated with Usher syndrome or BBS may cause non-syndromic RP $(14,15,57)$. Other examples arise from targeted-capture NGS. This can be confusing for the patient and requires thoughtful explanation and counseling. In some cases, it may require redefining the family's disease. Reconciling the clinical phenotype, family history and genetic findings is a critical, new step in the diagnosis of inherited retinal diseases.

\section{Acknowledgments}

Supported by grants from the Foundation Fighting Blindness and NIH grant EY007142. Dr Daiger is Director of a CLIA Certified Laboratory in the eyeGENE® Ophthalmic Disease Genotyping Network which includes financial support for genetic testing.

\section{References}

1. Daiger SP, Bowne SJ, Sullivan LS. Perspective on genes and mutations causing retinitis pigmentosa. Arch Ophthalmol. 2007; 125:151-158. [PubMed: 17296890]

2. Haim M. Epidemiology of retinitis pigmentosa in Denmark. Acta Ophthalmol Scand Suppl. 2002; 233:1-34. [PubMed: 11921605]

3. Heckenlively, JR.; Daiger, SP. Hereditary retinal and choroidal degenerations, in Emery and Rimoin's Principals and Practice of Medical Genetics. 5th edn.. Churchill Livingston Elsevier; Philadelphia: 2007. p. 3197-3227.Chapter 147

4. Berger W, Kloeckener-Gruissem B, Neidhardt J. The molecular basis of human retinal and vitreoretinal diseases. Prog Retin Eye Res. 2010; 29:335-375. [PubMed: 20362068]

5. [Accessed on May 2013] RetNet. The Retinal Information Network 2013. Retrieved from http:// www.sph.uth.tmc.edu/RetNet/

6. [Accessed on May 2013] HGMD. Human Gene Mutation Database (Biobase Biological Databases) 2013. Retrieved from http://www.hgmd.cf.ac.uk/

7. Wright AF, Chakarova CF, Abd El-Aziz MM, Bhattacharya SS. Photoreceptor degeneration: genetic and mechanistic dissection of a complex trait. Nat Rev Genet. 2010; 11:273-284. [PubMed: 20212494]

8. Fokkema IF, Taschner PE, Schaafsma GC, Celli J, Laros JF, den Dunnen JT. LOVD v.2.0: the next generation in gene variant databases. Hum Mutat. 2011; 32:557-563. [PubMed: 21520333]

9. Bowne SJ, Humphries MM, Sullivan LS, et al. A dominant-acting mutation in RPE65 identified by whole-exome sequencing causes retinitis pigmentosa with choroidal involvement. Euro J Hum Genet. 2011; 10:1074-1081.

10. Dryja TP, McGee TL, Hahn LB, et al. Mutations within the rhodopsin gene in patients with autosomal dominant retinitis pigmentosa. N Engl J Med. 1990; 323:1302-1307. [PubMed: 2215617]

11. Marlhens F, Bareil C, Griffoin JM, et al. Mutations in RPE65 cause Leber's congenital amaurosis. Nat Genet. 1997; 17:139-141. [PubMed: 9326927]

12. Morimura H, Fishman GA, Grover SA, Fulton AB, Berson EL, Dryja TP. Mutations in the RPE65 gene in patients with autosomal recessive retinitis pigmentosa or Leber congenital amaurosis. Proc Natl Acad Sci USA. 1998; 95:3088-3093. [PubMed: 9501220]

13. Rosenfeld PJ, Cowley GS, McGee TL, Sandberg MA, Berson EL, Dryja TP. A null mutation in the rhodopsin gene causes rod photoreceptor dysfunction and autosomal recessive retinitis pigmentosa. Nat Genet. 1992; 1:209-213. [PubMed: 1303237]

14. Khan MI, Kersten FF, Azam M, et al. CLRN1 mutations cause nonsyn-dromic retinitis pigmentosa. Ophthalmology. 2011; 118:1444-1448. [PubMed: 21310491]

15. Rivolta C, Sweklo EA, Berson EL, Dryja TP. Missense mutation in the USH2A gene: association with recessive retinitis pigmentosa without hearing loss. Am J Hum Genet. 2000; 66:1975-1198. [PubMed: 10775529] 
16. McGee TL, Devoto M, Ott J, Berson EL, Dryja TP. Evidence that the penetrance of mutations at the RP11 locus causing dominant retinitis pigmentosa is influenced by a gene linked to the homologous RP11 allele. Am J Hum Genet. 1997; 61:1059-1066. [PubMed: 9345108]

17. Sullivan LS, Bowne SJ, Seaman CR, et al. Genomic rearrangements of the PRPF31 gene account for $2.5 \%$ of autosomal dominant retinitis pigmentosa. Invest Ophthalmol Vis Sci. 2006; 47:45794588. [PubMed: 17003455]

18. Felbor U, Schilling H, Weber BH. Adult vitelliform macular dystrophy is frequently associated with mutations in the peripherin/RDS gene. Hum Mutat. 1997; 10:301-309. [PubMed: 9338584]

19. Sears JE, Aaberg TA Sr, Daiger SP, Moshfeghi DM. Splice site mutation in the peripherin/RDS gene associated with pattern dystrophy of the retina. Am J Ophthalmol. 2001; 132:693-699. [PubMed: 11704030]

20. Korn JM, Kuruvilla FG, McCarroll SA, et al. Integrated genotype calling and association analysis of SNPs, common copy number polymorphisms and rare CNVs. Nat Genet. 2008; 40:1253-1260. [PubMed: 18776909]

21. Chakarova CF, Khanna H, Shah AZ, et al. TOPORS, implicated in retinal degeneration, is a ciliacentrosomal protein. Hum Mol Genet. 2011; 20:975-987. [PubMed: 21159800]

22. Friedman JS, Ray JW, Waseem N, et al. Mutations in a BTB-Kelch protein, KLHL7, cause autosomal-dominant retinitis pigmentosa. Am J Hum Genet. 2009; 84:792-800. [PubMed: 19520207]

23. Li L, Nakaya N, Chavali VR, et al. A mutation in ZNF513, a putative regulator of photoreceptor development, causes autosomal-recessive retinitis pigmentosa. Am J Hum Genet. 2010; 87:400 409. [PubMed: 20797688]

24. Naz S, Riazuddin SA, Li L, et al. A novel locus for autosomal recessive retinitis pigmentosa in a consanguineous Pakistani family maps to chromosome 2p. Am J Ophthalmol. 2010; 149:861-866. [PubMed: 20227676]

25. Zhao C, Bellur DL, Lu S, et al. Autosomal-dominant retinitis pigmentosa caused by a mutation in SNRNP200, a gene required for unwinding of U4/U6 snRNAs. Am J Hum Genet. 2009; 85:617627. [PubMed: 19878916]

26. Littink KW, den Hollander AI, Cremers FP, Collin RW. The power of homozygosity mapping: discovery of new genetic defects in patients with retinal dystrophy. Adv Exp Med Biol. 2012; 723:345-351. [PubMed: 22183352]

27. Zelinger L, Banin E, Obolensky A, et al. A missense mutation in DHDDS, encoding dehydrodolichyl diphosphate synthase, is associated with autosomal-recessive retinitis pigmentosa in Ashkenazi Jews. Am J Hum Genet. 2011; 88:207-215. [PubMed: 21295282]

28. Bandah-Rozenfeld D, Mizrahi-Meissonnier L, Farhy C, et al. Homozy-gosity mapping reveals null mutations in FAM161A as a cause of autosomal-recessive retinitis pigmentosa. Am J Hum Genet. 2010; 87:382-391. [PubMed: 20705279]

29. Bandah-Rozenfeld D, Collin RW, Banin E, et al. Mutations in IMPG2, encoding interphotoreceptor matrix proteoglycan 2, cause autosomal-recessive retinitis pigmentosa. Am J Hum Genet. 2010; 87:199-208. [PubMed: 20673862]

30. Dvir L, Srour G, Abu-Ras R, Miller B, Shalev SA, Ben-Yosef T. Autosomal-recessive early-onset retinitis pigmentosa caused by a mutation in PDE6G, the gene encoding the gamma subunit of rod cGMP phosphodiesterase. Am J Hum Genet. 2010; 87:258-264. [PubMed: 20655036]

31. den Hollander AI, McGee TL, Ziviello C, et al. A homozygous missense mutation in the IRBP gene (RBP3) associated with autosomal recessive retinitis pigmentosa. Invest Ophthalmol Vis Sci. 2009; 50:1864-1872. [PubMed: 19074801]

32. Kurg A, Tonisson N, Georgiou I, Shumaker J, Tollett J, Metspalu A. Arrayed primer extension: solid-phase four-color DNA resequencing and mutation detection technology. Genet Test. 2000; 4:1-7. [PubMed: 10794354]

33. Tonisson, N.; Oitmaa, E.; Krjutskov, K., et al. Molecular diagnostics. Academic Press; Oxford: 2010.

34. Tonisson, N.; Oitmaa, E.; Krjutskov, K., et al. Arrayed primer extension microarrays for molecular diagnostics. Academic Press; Oxford: 2010. 
35. Tucker T, Marra M, Friedman JM. Massively parallel sequencing: the next big thing in genetic medicine. Am J Hum Genet. 2009; 85:142-154. [PubMed: 19679224]

36. Liu L, Li Y, Li S, et al. Comparison of next-generation sequencing systems. J Biomed Biotechnol. 2012; 2012:251364. [PubMed: 22829749]

37. Quail MA, Smith M, Coupland P, et al. A tale of three next generation sequencing platforms: comparison of Ion Torrent, Pacific Biosciences and Illumina MiSeq sequencers. BMC genomics. 2012; 13:341. [PubMed: 22827831]

38. Tucker BA, Scheetz TE, Mullins RF, et al. Exome sequencing and analysis of induced pluripotent stem cells identify the cilia-related gene male germ cell-associated kinase (MAK) as a cause of retinitis pigmentosa. Proc Natl Acad Sci USA. 2011; 108:E569-E576. [PubMed: 21825139]

39. Zuchner S, Dallman J, Wen R, et al. Whole-exome sequencing links a variant in DHDDS to retinitis pigmentosa. Am J Hum Genet. 2011; 88:201-206. [PubMed: 21295283]

40. Schadt EE, Turner S, Kasarskis A. A window into third-generation sequencing. Hum Mol Genet. 2010; 19:R227-R240. [PubMed: 20858600]

41. Rehm HL. Disease-targeted sequencing: a cornerstone in the clinic. Nat Rev Genet. 2013; 14:295300. [PubMed: 23478348]

42. Audo I, Bujakowska KM, Leveillard T, et al. Development and application of a next-generationsequencing (NGS) approach to detect known and novel gene defects underlying retinal diseases. Orphanet J Rare Dis. 2012; 7:8. [PubMed: 22277662]

43. Chen X, Zhao K, Sheng X, et al. Targeted sequencing of 179 genes associated with hereditary retinal dystrophies and 10 candidate genes identifies novel and known mutations in patients with various retinal diseases. Invest Ophthalmol Vis Sci. 2013; 54:2186-2197. [PubMed: 23462753]

44. Glockle N, Kohl S, Mohr J, et al. Panel-based next generation sequencing as a reliable and efficient technique to detect mutations in unselected patients with retinal dystrophies. Eur J Hum Genet. 2013 Epub ahead of print.

45. Neveling K, Collin RW, Gilissen C, et al. Next-generation genetic testing for retinitis pigmentosa. Hum Mutat. 2012; 33:963-972. [PubMed: 22334370]

46. O'Sullivan J, Mullaney BG, Bhaskar SS, et al. A paradigm shift in the delivery of services for diagnosis of inherited retinal disease. J Med Genet. 2012; 49:322-326. [PubMed: 22581970]

47. Shanks ME, Downes SM, Copley RR, et al. Next-generation sequencing (NGS) as a diagnostic tool for retinal degeneration reveals a much higher detection rate in early-onset disease. Eur J Hum Genet. 2013; 21:274-280. [PubMed: 22968130]

48. Köhn L, Bowne SJ, Sullivan LS, et al. Breakpoint characterization of a novel approximately $59 \mathrm{~kb}$ genomic deletion on 19q13.42 in autosomal-dominant retinitis pigmentosa with incomplete penetrance. Eur J Hum Genet. 2009; 17:651-655. [PubMed: 19050727]

49. Fahim AT, Bowne SJ, Sullivan LS, et al. Allelic heterogeneity and genetic modifier loci contribute to clinical variation in males with X-linked retinitis pigmentosa due to RPGR mutations. PLoS ONE. 2011; 6:ie23021.

50. Daiger SP, Sullivan LS, Bowne SJ, et al. Application of whole-exome and retinal-capture nextgeneration DNA sequencing to identify disease-causing mutations in families with a diagnosis of autosomal dominant retinitis pigmentosa. Invest Ophthalmol Vis Sci. 2013 E-Abstract, ARVO Annual Meeting.

51. Branham K, Othman M, Brumm M, et al. Mutations in RPGR and RP2 account for $15 \%$ of males with simplex retinal degenerative disease. Invest Ophthalmol Vis Sci. 2012; 53:8232-8237. [PubMed: 23150612]

52. Sohocki MM, Daiger SP, Bowne SJ, et al. Prevalence of mutations causing retinitis pigmentosa and other inherited retinopathies. Hum Mutat. 2001; 17:42-51. [PubMed: 11139241]

53. Nishiguchi KM, Rivolta C. Genes associated with retinitis pigmentosa and allied diseases are frequently mutated in the general population. PLoS ONE. 2012; 7:e41902. [PubMed: 22848652]

54. Kajiwara K, Berson EL, Dryja TP. Digenic retinitis pigmentosa due to mutations at the unlinked peripherin/RDS and ROM1 loci. Science. 1994; 264:1604-1608. [PubMed: 8202715]

55. Katsanis N, Ansley SJ, Badano JL, et al. Triallelic inheritance in Bardet-Biedl syndrome, a Mendelian recessive disorder. Science. 2001; 293:2256-2259. [PubMed: 11567139] 
56. Churchill JD, Bowne SJ, Sullivan LS, et al. Mutations in the X-linked retinitis pigmentosa genes RPGR and RP2 found in $8.5 \%$ of families with a provisional diagnosis of autosomal dominant retinitis pigmentosa. Invest Ophthalmol Vis Sci. 2013; 54:1411-1416. [PubMed: 23372056]

57. Riazuddin SA, Iqbal M, Wang Y, et al. A splice-site mutation in a retina-specific exon of BBS8 causes nonsyndromic retinitis pigmentosa. Am J Hum Genet. 2010; 86:805-812. [PubMed: 20451172] 


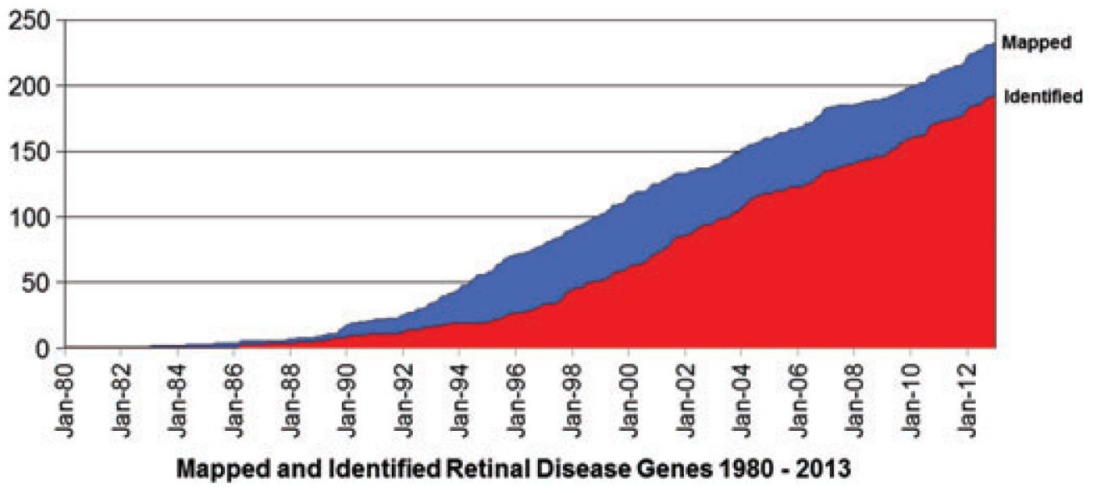

Fig. 1.

Mapped and identified retinal disease genes over three decades. 
Table 1

Genes causing non-syndromic retinitis pigmentosa ${ }^{a}$

\begin{tabular}{|c|c|c|c|c|c|c|}
\hline & Symbol & Location & Protein & $\begin{array}{l}\text { Type of retinitis } \\
\text { pigmentosa }\end{array}$ & Other diseases & Mutations \\
\hline 1 & ABCA4 & $1 \mathrm{p} 22.1$ & $\begin{array}{l}\text { ATP-binding cassette } \\
\text { transporter - retinal }\end{array}$ & $\begin{array}{l}\text { Autosomal } \\
\text { recessive }\end{array}$ & $\begin{array}{l}\text { Recessive macular } \\
\text { dystrophy; recessive } \\
\text { fundus flavimaculatus; } \\
\text { recessive cone-rod } \\
\text { dystrophy }\end{array}$ & 680 \\
\hline 2 & BEST1 & $11 \mathrm{q} 12.3$ & Bestrophin 1 & $\begin{array}{l}\text { Autosomal } \\
\text { dominant; } \\
\text { autosomal } \\
\text { recessive }\end{array}$ & $\begin{array}{l}\text { Dominant vitreo- } \\
\text { retinochoroidopathy; } \\
\text { recessive } \\
\text { bestrophinopathy; } \\
\text { dominant Best type } \\
\text { macular dystrophy }\end{array}$ & 232 \\
\hline 3 & C2ORF71 & $2 \mathrm{p} 23.2$ & $\begin{array}{l}\text { Chromosome } 2 \text { open } \\
\text { reading frame } 71\end{array}$ & $\begin{array}{l}\text { Autosomal } \\
\text { recessive }\end{array}$ & & 13 \\
\hline 4 & C8ORF37 & $8 \mathrm{q} 22.1$ & $\begin{array}{l}\text { Chromosome } 8 \text { open } \\
\text { reading frame } 37\end{array}$ & $\begin{array}{l}\text { Autosomal } \\
\text { recessive }\end{array}$ & $\begin{array}{l}\text { Recessive cone-rod } \\
\text { dystrophy }\end{array}$ & 4 \\
\hline 5 & CA4 & $17 \mathrm{q} 23.2$ & Carbonic anhydrase IV & $\begin{array}{l}\text { Autosomal } \\
\text { dominant }\end{array}$ & & 6 \\
\hline 6 & CERKL & $2 q 31.3$ & $\begin{array}{l}\text { Ceramide kinase-like } \\
\text { protein }\end{array}$ & $\begin{array}{l}\text { Autosomal } \\
\text { recessive }\end{array}$ & $\begin{array}{l}\text { Recessive cone-rod } \\
\text { dystrophy with inner } \\
\text { retinopathy }\end{array}$ & 8 \\
\hline 7 & CLRN1 & $3 q 25.1$ & Clarin-1 & $\begin{array}{l}\text { Autosomal } \\
\text { recessive }\end{array}$ & $\begin{array}{l}\text { Recessive Usher } \\
\text { syndrome }\end{array}$ & 23 \\
\hline 8 & CNGA1 & $4 \mathrm{p} 12$ & $\begin{array}{l}\text { Rod cGMP-gated channel } \\
\text { alpha subunit }\end{array}$ & $\begin{array}{l}\text { Autosomal } \\
\text { recessive }\end{array}$ & & 8 \\
\hline 9 & CNGB1 & $16 \mathrm{q} 13$ & $\begin{array}{l}\text { Rod cGMP-gated channel } \\
\text { beta subunit }\end{array}$ & $\begin{array}{l}\text { Autosomal } \\
\text { recessive }\end{array}$ & & 6 \\
\hline 23 & CRB1 & $1 \mathrm{q} 31.3$ & Crumbs homolog 1 & $\begin{array}{l}\text { Autosomal } \\
\text { recessive }\end{array}$ & $\begin{array}{l}\text { Recessive Leber } \\
\text { congenital amaurosis; } \\
\text { dominant pigmented } \\
\text { paravenous } \\
\text { chorioretinal atrophy }\end{array}$ & 183 \\
\hline 11 & CRX & $19 \mathrm{q} 13.32$ & $\begin{array}{l}\text { Cone-rod otx-like } \\
\text { photoreceptor } \\
\text { homeobox transcription } \\
\text { factor }\end{array}$ & $\begin{array}{l}\text { Autosomal } \\
\text { dominant }\end{array}$ & $\begin{array}{l}\text { Recessive, dominant and } \\
\text { de novo Leber } \\
\text { congenital amaurosis; } \\
\text { dominant cone-rod } \\
\text { dystrophy }\end{array}$ & 51 \\
\hline 12 & DHDDS & $1 \mathrm{p} 36.11$ & $\begin{array}{l}\text { Dehydrodolichyl } \\
\text { diphosphate synthetase }\end{array}$ & $\begin{array}{l}\text { Autosomal } \\
\text { recessive }\end{array}$ & & 1 \\
\hline 13 & EYS & $6 q 12$ & $\begin{array}{l}\text { Eyes shut/spacemaker } \\
\quad \text { (Drosophila) homolog }\end{array}$ & $\begin{array}{l}\text { Autosomal } \\
\text { recessive }\end{array}$ & & 118 \\
\hline 14 & FAM161A & $2 \mathrm{p} 15$ & $\begin{array}{l}\text { Family with sequence } \\
\quad \text { similarity } 161 \text { member A }\end{array}$ & $\begin{array}{l}\text { Autosomal } \\
\text { recessive }\end{array}$ & & 6 \\
\hline 15 & FSCN2 & $17 \mathrm{q} 25.3$ & $\begin{array}{l}\text { Retinal fascin homolog } 2 \\
\text { actin bundling protein }\end{array}$ & $\begin{array}{l}\text { Autosomal } \\
\text { dominant }\end{array}$ & $\begin{array}{l}\text { Dominant macular } \\
\text { dystrophy }\end{array}$ & 1 \\
\hline 16 & GUCA1B & $6 \mathrm{p} 21.1$ & $\begin{array}{l}\text { Guanylate cyclase } \\
\text { activating protein 1B }\end{array}$ & $\begin{array}{l}\text { Autosomal } \\
\text { dominant }\end{array}$ & $\begin{array}{l}\text { Dominant macular } \\
\text { dystrophy }\end{array}$ & 3 \\
\hline 17 & IDH3B & 20p13 & $\begin{array}{l}\text { NAD(+)-specific isocitrate } \\
\text { dehydrogenase } 3 \text { beta }\end{array}$ & $\begin{array}{l}\text { Autosomal } \\
\text { recessive }\end{array}$ & & 2 \\
\hline 18 & IMPDH1 & $7 \mathrm{q} 32.1$ & $\begin{array}{l}\text { Inosine monophosphate } \\
\text { dehydrogenase } 1\end{array}$ & $\begin{array}{l}\text { Autosomal } \\
\text { dominant }\end{array}$ & $\begin{array}{l}\text { Dominant Leber } \\
\text { congenital amaurosis }\end{array}$ & 14 \\
\hline 19 & IMPG2 & $3 q 12.3$ & $\begin{array}{l}\text { Interphotoreceptor matrix } \\
\text { proteoglycan } 2\end{array}$ & $\begin{array}{l}\text { Autosomal } \\
\text { recessive }\end{array}$ & & 10 \\
\hline
\end{tabular}




\begin{tabular}{|c|c|c|c|c|c|c|}
\hline & Symbol & Location & Protein & $\begin{array}{l}\text { Type of retinitis } \\
\text { pigmentosa }\end{array}$ & Other diseases & Mutations \\
\hline 20 & KLHL7 & $7 \mathrm{p} 15.3$ & $\begin{array}{l}\text { Kelch-like } 7 \text { protein } \\
\quad(\text { Drosophila })\end{array}$ & $\begin{array}{l}\text { Autosomal } \\
\text { dominant }\end{array}$ & & 3 \\
\hline 21 & LRAT & $4 q 32.1$ & $\begin{array}{l}\text { Lecithin retinol } \\
\text { acyltransferase }\end{array}$ & $\begin{array}{l}\text { Autosomal } \\
\text { recessive }\end{array}$ & $\begin{array}{l}\text { Recessive Leber } \\
\text { congenital amaurosis }\end{array}$ & 10 \\
\hline 22 & MAK & $6 \mathrm{p} 24.2$ & $\begin{array}{l}\text { Male germ-cell associated } \\
\text { kinase }\end{array}$ & $\begin{array}{l}\text { Autosomal } \\
\text { recessive }\end{array}$ & & 9 \\
\hline 23 & MERTK & $2 q 13$ & $\begin{array}{l}\text { c-mer protooncogene } \\
\text { receptor tyrosine kinase }\end{array}$ & $\begin{array}{l}\text { Autosomal } \\
\text { recessive }\end{array}$ & & 27 \\
\hline 24 & NR2E3 & $15 q 23$ & $\begin{array}{l}\text { Nuclear receptor } \\
\text { subfamily } 2 \text { group E3 }\end{array}$ & $\begin{array}{l}\text { Autosomal } \\
\text { dominant; } \\
\text { autosomal } \\
\text { recessive }\end{array}$ & $\begin{array}{l}\text { Recessive Stargardt } \\
\text { disease; } \\
\text { Goldmann-Favre } \\
\text { syndrome; recessive } \\
\text { enhanced S-cone } \\
\text { syndrome }\end{array}$ & 45 \\
\hline 25 & NRL & $14 \mathrm{q} 11.2$ & Neural retina lucine zipper & $\begin{array}{l}\text { Autosomal } \\
\text { dominant; } \\
\text { autosomal } \\
\text { recessive }\end{array}$ & $\begin{array}{l}\text { Recessive retinitis } \\
\text { pigmentosa }\end{array}$ & 14 \\
\hline 26 & OFD1 & $\mathrm{Xp} 22.2$ & $\begin{array}{l}\text { Oral-facial-digital } \\
\text { syndrome } 1 \text { protein }\end{array}$ & X-linked & $\begin{array}{l}\text { Orofaciodigital syndrome } \\
\text { 1, Simpson-Golabi- } \\
\text { Behmel syndrome } \\
2\end{array}$ & 127 \\
\hline 27 & PDE6A & $5 q 33.1$ & $\begin{array}{l}\text { cGMP phosphodiesterase } \\
\text { alpha subunit }\end{array}$ & $\begin{array}{l}\text { Autosomal } \\
\text { recessive }\end{array}$ & & 16 \\
\hline 28 & PDE6B & $4 \mathrm{p} 16.3$ & $\begin{array}{l}\text { Rod cGMP } \\
\text { phosphodiesterase } \\
\text { beta subunit }\end{array}$ & $\begin{array}{l}\text { Autosomal } \\
\text { recessive }\end{array}$ & $\begin{array}{l}\text { Dominant congenital } \\
\text { stationary night } \\
\text { blindness }\end{array}$ & 39 \\
\hline 29 & PDE6G & $17 \mathrm{q} 25.3$ & $\begin{array}{l}\text { Phosphodiesterase 6G } \\
\text { cGMP-specific rod } \\
\text { gamma }\end{array}$ & $\begin{array}{l}\text { Autosomal } \\
\text { recessive }\end{array}$ & & 1 \\
\hline 30 & PRCD & $17 \mathrm{q} 25.1$ & $\begin{array}{l}\text { Progressive rod-cone } \\
\text { degeneration protein }\end{array}$ & $\begin{array}{l}\text { Autosomal } \\
\text { recessive }\end{array}$ & & 2 \\
\hline 31 & PROM1 & $4 \mathrm{p} 15.32$ & Prominin 1 & $\begin{array}{l}\text { Autosomal } \\
\text { recessive }\end{array}$ & $\begin{array}{l}\text { Dominant Stargardt-like } \\
\text { and bulls eye macular } \\
\text { dystrophy; dominant } \\
\text { cone-rod dystrophy }\end{array}$ & 9 \\
\hline 32 & PRPF3 & $1 \mathrm{q} 21.2$ & $\begin{array}{l}\text { Human homolog of yeast } \\
\text { pre-mRNA splicing } \\
\text { factor } 3\end{array}$ & $\begin{array}{l}\text { Autosomal } \\
\text { dominant }\end{array}$ & & 3 \\
\hline 33 & PRPF6 & $20 q 13.33$ & $\begin{array}{l}\text { Human homolog of yeast } \\
\text { pre-mRNA splicing } \\
\text { factor } 6\end{array}$ & $\begin{array}{l}\text { Autosomal } \\
\text { dominant }\end{array}$ & & 2 \\
\hline 34 & PRPF8 & $17 \mathrm{p} 13.3$ & $\begin{array}{l}\text { Human homolog of yeast } \\
\text { pre-mRNA splicing } \\
\text { factor C8 }\end{array}$ & $\begin{array}{l}\text { Autosomal } \\
\text { dominant }\end{array}$ & & 21 \\
\hline 35 & PRPF31 & $19 q 13.42$ & $\begin{array}{l}\text { Human homolog of yeast } \\
\text { pre-mRNA splicing } \\
\text { factor } 31\end{array}$ & $\begin{array}{l}\text { Autosomal } \\
\text { dominant }\end{array}$ & & 65 \\
\hline 36 & PRPH2 & $6 \mathrm{p} 21.1$ & Peripherin 2 & $\begin{array}{l}\text { Autosomal } \\
\text { dominant; } \\
\text { digenic with } \\
\text { ROM1 }\end{array}$ & $\begin{array}{l}\text { Dominant macular } \\
\text { dystrophy; dominant } \\
\text { vitelliform MD; } \\
\text { dominant cone-rod } \\
\text { dystrophy; dominant } \\
\text { central areolar choroidal } \\
\text { dystrophy }\end{array}$ & 123 \\
\hline 37 & RBP3 & $10 q 11.22$ & $\begin{array}{l}\text { Retinol binding protein } 3 \text {, } \\
\text { interstitial }\end{array}$ & $\begin{array}{l}\text { Autosomal } \\
\text { recessive }\end{array}$ & & 2 \\
\hline
\end{tabular}




\begin{tabular}{|c|c|c|c|c|c|c|}
\hline & Symbol & Location & Protein & $\begin{array}{l}\text { Type of retinitis } \\
\text { pigmentosa }\end{array}$ & Other diseases & Mutations \\
\hline 38 & RDH12 & $14 \mathrm{q} 24.1$ & Retinol dehydrogenase 12 & $\begin{array}{l}\text { Autosomal } \\
\text { dominant; } \\
\text { autosomal } \\
\text { recessive }\end{array}$ & $\begin{array}{l}\text { Recessive Leber } \\
\text { congenital amaurosis }\end{array}$ & 66 \\
\hline 39 & RGR & $10 \mathrm{q} 23.1$ & $\begin{array}{l}\text { RPE-retinal G } \\
\text { protein-coupled } \\
\text { receptor }\end{array}$ & $\begin{array}{l}\text { Autosomal } \\
\text { recessive }\end{array}$ & $\begin{array}{l}\text { Dominant choroidal } \\
\text { sclerosis }\end{array}$ & 7 \\
\hline 40 & RHO & $3 q 22.1$ & Rhodopsin & $\begin{array}{l}\text { Autosomal } \\
\text { dominant; } \\
\text { autosomal } \\
\text { recessive }\end{array}$ & $\begin{array}{l}\text { Dominant congenital } \\
\text { stationary night } \\
\text { blindness }\end{array}$ & 161 \\
\hline 41 & RLBP1 & $15 \mathrm{q} 26.1$ & $\begin{array}{l}\text { Retinaldehyde-binding } \\
\text { protein } 1\end{array}$ & $\begin{array}{l}\text { Autosomal } \\
\text { recessive }\end{array}$ & $\begin{array}{l}\text { Recessive Bothnia } \\
\text { dystrophy; recessive } \\
\text { retinitis punctata } \\
\text { albescens; recessive } \\
\text { Newfoundland } \\
\text { rod-cone dystrophy }\end{array}$ & 20 \\
\hline 42 & ROM1 & $11 \mathrm{q} 12.3$ & $\begin{array}{l}\text { Retinal outer segment } \\
\text { membrane protein } 1\end{array}$ & $\begin{array}{l}\text { Autosomal } \\
\text { dominant; } \\
\text { digenic w/ } \\
\text { PRPH2 }\end{array}$ & & 11 \\
\hline 43 & RP1 & $8 \mathrm{q} 12.1$ & $\mathrm{RP} 1$ protein & $\begin{array}{l}\text { Autosomal } \\
\text { dominant; } \\
\text { autosomal } \\
\text { recessive }\end{array}$ & $\begin{array}{l}\text { Autosomal dominant and } \\
\text { recessive }\end{array}$ & 67 \\
\hline 44 & RP2 & $\mathrm{Xp} 11.23$ & $\begin{array}{l}\text { Retinitis pigmentosa } 2 \\
\text { (X-linked) }\end{array}$ & X-linked & & 76 \\
\hline 45 & RP9 & $7 \mathrm{p} 14.3$ & $\begin{array}{l}\text { RP9 protein or } \\
\text { PIM1-kinase associated } \\
\text { protein } 1\end{array}$ & $\begin{array}{l}\text { Autosomal } \\
\text { dominant }\end{array}$ & & 2 \\
\hline 46 & RPE65 & $1 \mathrm{p} 31.2$ & $\begin{array}{l}\text { Retinal pigment } \\
\text { epithelium-specific } \\
65 \mathrm{kDa} \text { protein }\end{array}$ & $\begin{array}{l}\text { Autosomal } \\
\text { dominant; } \\
\text { autosomal } \\
\text { recessive }\end{array}$ & $\begin{array}{l}\text { Recessive Leber } \\
\text { congenital amaurosis }\end{array}$ & 134 \\
\hline 47 & RPGR & Xp11.4 & $\begin{array}{c}\text { Retinitis pigmentosa } \\
\text { GTPase regulator }\end{array}$ & X-linked & $\begin{array}{l}\text { X-linked cone dystrophy } \\
1 \text {; X-linked atrophic } \\
\text { macular dystrophy }\end{array}$ & 151 \\
\hline 48 & SAG & $2 q 37.1$ & Arrestin (s-antigen) & $\begin{array}{l}\text { Autosomal } \\
\text { recessive }\end{array}$ & Recessive Oguchi disease & 11 \\
\hline 49 & SEMA4A & $1 \mathrm{q} 22$ & Semaphorin 4A & $\begin{array}{c}\text { Autosomal } \\
\text { dominant }\end{array}$ & $\begin{array}{l}\text { Dominant cone-rod } \\
\text { dystrophy }\end{array}$ & 3 \\
\hline 50 & SNRNP200 & $2 \mathrm{q} 11.2$ & $\begin{array}{l}\text { Small nuclear } \\
\text { ribonucleoprotein } \\
200 \mathrm{kDa} \text { (U5) }\end{array}$ & $\begin{array}{l}\text { Autosomal } \\
\text { dominant }\end{array}$ & & 7 \\
\hline 51 & SPATA7 & $14 \mathrm{q} 31.3$ & $\begin{array}{l}\text { Spermatogenesis } \\
\text { associated protein } 7\end{array}$ & $\begin{array}{l}\text { Autosomal } \\
\text { recessive }\end{array}$ & $\begin{array}{l}\text { Recessive Leber } \\
\text { congenital amaurosis }\end{array}$ & 15 \\
\hline 52 & TOPORS & $9 \mathrm{p} 21.1$ & $\begin{array}{l}\text { Topoisomerase I binding } \\
\text { arginine/serine rich } \\
\text { protein }\end{array}$ & $\begin{array}{c}\text { Autosomal } \\
\text { dominant }\end{array}$ & & 8 \\
\hline 53 & TTC8 & $14 \mathrm{q} 32.11$ & $\begin{array}{l}\text { Tetratricopeptide repeat } \\
\text { domain } 8\end{array}$ & $\begin{array}{l}\text { Autosomal } \\
\text { recessive }\end{array}$ & $\begin{array}{l}\text { Recessive Bardet-Biedl } \\
\text { syndrome }\end{array}$ & 14 \\
\hline 54 & TULP1 & $6 \mathrm{p} 21.31$ & Tubby-like protein 1 & $\begin{array}{l}\text { Autosomal } \\
\text { recessive }\end{array}$ & $\begin{array}{l}\text { Recessive Leber } \\
\text { congenital amaurosis }\end{array}$ & 31 \\
\hline 55 & USH2A & $1 \mathrm{q} 41$ & Usherin & $\begin{array}{l}\text { Autosomal } \\
\text { recessive }\end{array}$ & $\begin{array}{l}\text { Recessive Usher } \\
\text { syndrome }\end{array}$ & 392 \\
\hline \multirow[t]{2}{*}{56} & ZNF513 & $2 \mathrm{p} 23.3$ & Zinc finger protein 513 & $\begin{array}{l}\text { Autosomal } \\
\text { recessive }\end{array}$ & & 1 \\
\hline & & & & & Total & 3064 \\
\hline
\end{tabular}

Clin Genet. Author manuscript; available in PMC 2014 August 01. 


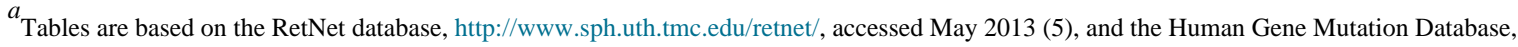
http://www.hgmd.cf.ac.uk/, accessed May 2013 (6). References are in RetNet. Some genes appear in more than one table so the sum total of distinct genes in the tables, 82 , is less than the sum of the three tables together. 
Table 2

Genes causing Usher syndrome ${ }^{a}$

\begin{tabular}{|c|c|c|c|c|c|c|}
\hline & Symbol & Location & Protein & $\begin{array}{l}\text { Type of Usher } \\
\text { syndrome }\end{array}$ & Other diseases & Mutations \\
\hline 1 & ABHD12 & $2 \mathrm{p} 11.21$ & $\begin{array}{l}\text { Abhydrolase domain } \\
\text { containing protein } \\
12\end{array}$ & $\begin{array}{l}\text { Autosomal } \\
\text { recessive type } \\
\text { 3-like }\end{array}$ & $\begin{array}{l}\text { Recessive PHARC } \\
\text { syndrome type }\end{array}$ & 5 \\
\hline 2 & $\mathrm{CDH} 23$ & $10 \mathrm{q} 22.1$ & Cadherin-like gene 23 & $\begin{array}{l}\text { Autosomal } \\
\text { recessive 1d; } \\
\text { digenic with } \\
\text { PCDH15 }\end{array}$ & $\begin{array}{l}\text { Recessive deafness } \\
\text { without retinitis } \\
\text { pigmentosa }\end{array}$ & 167 \\
\hline 3 & CIB2 & $15 \mathrm{q} 25.1$ & $\begin{array}{l}\text { Calcium and integrin } \\
\text { binding family } \\
\text { member } 2\end{array}$ & $\begin{array}{l}\text { Autosomal } \\
\quad \text { recessive type } 1 \mathrm{~J}\end{array}$ & & 7 \\
\hline 4 & CLRN1 & $3 \mathrm{q} 25.1$ & Clarin-1 & $\begin{array}{l}\text { Autosomal } \\
\quad \text { recessive type } 3\end{array}$ & $\begin{array}{l}\text { Recessive retinitis } \\
\text { pigmentosa }\end{array}$ & see RP \\
\hline 5 & DFNB31 & $9 q 32$ & Whirlin & $\begin{array}{l}\text { Autosomal } \\
\quad \text { recessive type } 2\end{array}$ & $\begin{array}{l}\text { Recessive deafness } \\
\text { without retinitis } \\
\text { pigmentosa }\end{array}$ & 13 \\
\hline 6 & GPR98 & $5 \mathrm{q} 14.3$ & $\begin{array}{l}\text { Monogenic audiogenic } \\
\text { seizure susceptibility } \\
1 \text { homolog }\end{array}$ & $\begin{array}{l}\text { Autosomal } \\
\quad \text { recessive type } 2\end{array}$ & $\begin{array}{l}\text { Dominant/recessive } \\
\text { febrile convulsions }\end{array}$ & 54 \\
\hline 7 & HARS & $5 \mathrm{q} 31.3$ & $\begin{array}{l}\text { Histidyl-tRNA } \\
\text { synthetase }\end{array}$ & $\begin{array}{l}\text { Autosomal } \\
\text { recessive }\end{array}$ & $\begin{array}{l}\text { Recessive HARS } \\
\text { syndrome }\end{array}$ & 2 \\
\hline 8 & MYO7A & $11 q 13.5$ & myosin VIIA & $\begin{array}{l}\text { Recessive type } 1 \mathrm{~b} \text {; } \\
\text { recessive } \\
\text { USH3-like }\end{array}$ & $\begin{array}{l}\text { Recessive deafness } \\
\text { without retinitis } \\
\text { pigmentosa }\end{array}$ & 263 \\
\hline 9 & PCDH15 & $10 \mathrm{q} 21.1$ & Protocadherin 15 & $\begin{array}{l}\text { Autosomal } \\
\text { recessive type 1f; } \\
\text { digenic with } \\
\text { CDH23 }\end{array}$ & $\begin{array}{l}\text { Recessive deafness } \\
\text { without retinitis } \\
\text { pigmentosa }\end{array}$ & 52 \\
\hline 10 & USH1C & $11 \mathrm{p} 15.1$ & harmonin & $\begin{array}{l}\text { Autosomal } \\
\text { recessive } \\
\text { Acadian }\end{array}$ & $\begin{array}{l}\text { Recessive deafness } \\
\text { without retinitis } \\
\text { pigmentosa; recessive } \\
\text { RP with late-onset } \\
\text { hearing loss }\end{array}$ & 26 \\
\hline 11 & USH1G & $17 \mathrm{q} 25.1$ & $\begin{array}{l}\text { Human homolog of } \\
\text { mouse scaffold } \\
\text { protein containing } \\
\text { ankyrin repeats and } \\
\text { SAM domain }\end{array}$ & $\begin{array}{l}\text { Autosomal } \\
\text { recessive Usher } \\
\text { syndrome }\end{array}$ & & 11 \\
\hline \multirow[t]{2}{*}{12} & USH2A & $1 \mathrm{q} 41$ & Usherin & $\begin{array}{l}\text { Autosomal } \\
\text { recessive type } 2 \mathrm{a}\end{array}$ & $\begin{array}{l}\text { Recessive retinitis } \\
\text { pigmentosa }\end{array}$ & see RP \\
\hline & & & & & Total & 600 \\
\hline
\end{tabular}

$\mathrm{RP}$, retinitis pigmentosa.

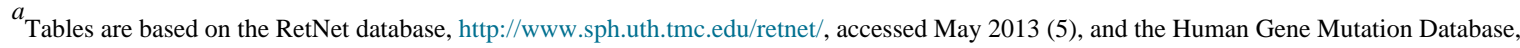
http://www.hgmd.cf.ac.uk/, accessed May 2013 (6). References are in RetNet. Some genes appear in more than one table so the sum total of distinct genes in the tables, 82 , is less than the sum of the three tables together. 
Table 3

Genes causing Bardet-Biedl syndrome (BBS) ${ }^{a}$

\begin{tabular}{|c|c|c|c|c|c|c|}
\hline & Symbol & Location & Protein & Type of BBS & Other diseases & Mutations \\
\hline 1 & ARL6 & $3 q 11.2$ & $\begin{array}{l}\text { ADP-ribosylation } \\
\text { factor-like } 6\end{array}$ & Autosomal recessive & & 14 \\
\hline 2 & BBS1 & $11 \mathrm{q} 13$ & BBS1 protein & Autosomal recessive & & 65 \\
\hline 3 & BBS2 & $16 \mathrm{q} 12.2$ & BBS2 protein & Autosomal recessive & & 61 \\
\hline 4 & BBS4 & $15 \mathrm{q} 24.1$ & BBS4 protein & Autosomal recessive & & 29 \\
\hline 5 & BBS5 & $2 \mathrm{q} 31.1$ & $\begin{array}{l}\text { Flagellar apparatus-basal } \\
\text { body protein } \\
\text { DKFZp7621194 }\end{array}$ & Autosomal recessive & & 18 \\
\hline 6 & BBS7 & $4 q 27$ & BBS7 protein & Autosomal recessive & & 26 \\
\hline 7 & BBS9 & $7 \mathrm{p} 14.3$ & $\begin{array}{l}\text { Parathyroid } \\
\text { hormone-responsive } \\
\text { B1 protein }\end{array}$ & Autosomal recessive & & 27 \\
\hline 8 & BBS10 & $12 q 21.2$ & $\begin{array}{l}\text { BBS10 (C12orf58) } \\
\text { chaperonin }\end{array}$ & Autosomal recessive & & 76 \\
\hline 9 & BBS12 & $4 q 27$ & BBS12 protein & Autosomal recessive & & 45 \\
\hline 10 & CEP290 & $12 q 21.32$ & $\begin{array}{l}\text { Centrosomal protein } \\
290 \mathrm{kDa}\end{array}$ & Autosomal recessive & $\begin{array}{l}\text { Recessive Joubert } \\
\text { syndrome; recessive } \\
\text { Leber congenital } \\
\text { amaurosis; recessive } \\
\text { Meckel syndrome; } \\
\text { recessive Senior-Loken } \\
\text { syndrome }\end{array}$ & 157 \\
\hline 11 & INPP5E & $9 q 34.3$ & $\begin{array}{l}\text { Inositol polyphosphate-5- } \\
\text { phosphatase } \\
\text { E }\end{array}$ & Autosomal recessive & $\begin{array}{l}\text { Recessive MORM syndrome; recessive } \\
\text { Joubert syndrome }\end{array}$ & 7 \\
\hline 12 & LZTFL1 & $3 \mathrm{p} 21.31$ & $\begin{array}{l}\text { Leucine zipper } \\
\text { transcription factor-like } \\
1\end{array}$ & Autosomal recessive & & 1 \\
\hline 13 & MKKS & $20 \mathrm{p} 12.2$ & $\begin{array}{l}\text { McKusick-Kaufman } \\
\text { syndrome protein }\end{array}$ & Autosomal recessive & & 44 \\
\hline 14 & MKS1 & $17 q 22$ & $\begin{array}{l}\text { Meckel syndrome type } 1 \\
\text { protein }\end{array}$ & Autosomal recessive & $\begin{array}{l}\text { Recessive Meckel } \\
\text { syndrome }\end{array}$ & 26 \\
\hline 15 & SDCCAG8 & $1 q 43$ & $\begin{array}{l}\text { Serologically defined } \\
\quad \text { colon cancer antigen } 8\end{array}$ & Autosomal recessive & $\begin{array}{l}\text { Recessive } \\
\text { ciliopathy-related } \\
\text { nephronophthisis, }\end{array}$ & 13 \\
\hline 16 & TRIM32 & $9 q 33.1$ & $\begin{array}{l}\text { Tripartite motif-containing } \\
\text { protein } 32\end{array}$ & Autosomal recessive & $\begin{array}{l}\text { Recessive limb-girdle } \\
\text { muscular dystrophy }\end{array}$ & 8 \\
\hline \multirow[t]{2}{*}{17} & TTC8 & $14 q 32.11$ & $\begin{array}{l}\text { Tetratricopeptide repeat } \\
\text { domain } 8\end{array}$ & Autosomal recessive & $\begin{array}{l}\text { Recessive retinitis } \\
\text { pigmentosa }\end{array}$ & see RP \\
\hline & & & & & Total & 617 \\
\hline
\end{tabular}

$\mathrm{RP}$, retinitis pigmentosa.

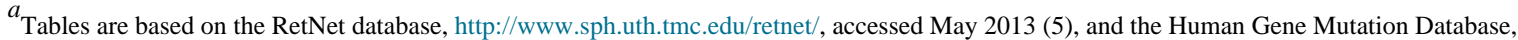
http://www.hgmd.cf.ac.uk/, accessed May 2013 (6). References are in RetNet. Some genes appear in more than one table so the sum total of distinct genes in the tables, 82 , is less than the sum of the three tables together. 